\title{
Identification and Characterization of Cancer Stem Cells Using Flow Cytometry
}

\author{
Yasunari Kanda \\ Division of Pharmacology, National Institute of Health Sciences \\ Japan
}

\section{Introduction}

Tumors are heterogeneous in their cellular morphology, proliferation rate, differentiation grade, genetic lesions, and therapeutic response. The cellular and molecular mechanisms that cause tumor heterogeneity are largely unknown. Growing evidence suggests that tumors are organized in a hierarchy of heterogeneous cell populations and are made and maintained from a small population of stem/stem-like cells called cancer stem cells (CSCs). CSCs are defined on the basis of characteristics such as high tumorigenicity, self-renewal, and differentiation that contribute to heterogeneity. Cancer recurrence is thought to be due to CSCs that are resistant to chemotherapy and radiation.

Dick and his coworkers first reported that all cancer phenotypes present in acute myeloid leukemia (AML) were derived from a few rare populations $(0.1-1 \%$ of total cells) (Bonnet \& Dick, 1997). These leukemic stem cells were isolated from the peripheral blood of AML patients by the surface markers $\mathrm{CD} 34^{+} / \mathrm{CD} 38^{-}$, which are similar to those in normal hematopoietic stem cells. These CSCs had a much higher rate of self-renewal than normal stem cells and recapitulated the morphological features of the original malignancy when engrafted in immunodeficient mice. CSCs are thought to have the ability to self-renew and to produce heterogeneous tumors.

This discovery paved the way for the study of CSCs in solid tumors. Based on a similar approach of combined flow cytometry and xenotransplantation, many researchers attempted to isolate CSCs from other tumors. Since the isolation of rare CSCs is a crucial step, the method of CSC isolation using flow cytometry has been improved by using surface markers, side populations, and the ALDEFLUOR assay, as described below. Thus far, CSCs have been found in various solid tumors, including breast, brain, colon, pancreas, prostate, and ovarian tumors (Collins et al., 2005; Curley et al., 2009; Dalerba et al., 2007; Ponti et al., 2005; Singh et al., 2004).

It is still unclear how CSCs are generated. It has been speculated that normal stem cells in various tissues are malignantly transformed by multiple steps such as genetic and epigenetic mutations (Visvader \& Lindeman, 2008). A recent study suggests that the dedifferentiation of transformed malignant cells results in the production of CSCs (Gupta et al., 2011). Although there is still a lot of controversy regarding CSCs, a CSC model might provide a potential screening strategy for drug discovery (Gupta et al., 2009). Given the 
variation of CSCs both in primary specimens and established cancer cell lines, it is essential to characterize CSCs and to optimize the isolation protocol.

This review focuses on the current protocols to identify and characterize CSCs by flow cytometry. In particular, the isolation of CSCs from established breast cancer cell lines is used as a simple model. These protocols would provide new insights into the targeting of CSCs and the implications for cancer therapy.

\section{Sphere formation}

Normal stem cells have the ability to proliferate in suspension as non-adherent spheres. Neural stem cells and their derived progenitor cells can be enriched and expanded in vitro by their ability to form floating aggregates called neurospheres (Reynolds \& Weiss, 1992). These non-adherent spheres were enriched in stem/progenitor cells and were able to differentiate into neurons and glia. In these spheres, between $4 \%$ and $20 \%$ of the cells were stem cells whereas the other cells represented progenitor cells in different phases of differentiation (Weiss et al., 1996), suggesting that stem cells had been successfully enriched. The markers and receptors that regulate neural stem cell growth have been identified using this cell culture system (Hiramoto et al., 2007; Holmberg et al., 2005; Nagato et al., 2005).These non-adherent culture conditions were also adapted to other normal stem cells. Mammary stem cells that are grown in suspension form mammospheres, which are the equivalent of neurospheres (Dontu et al., 2003).

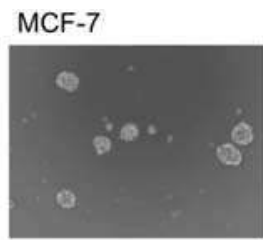

MDA-MB-231

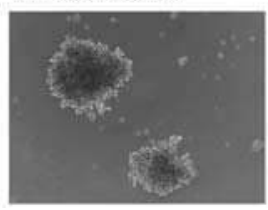

(A)
HCC1806

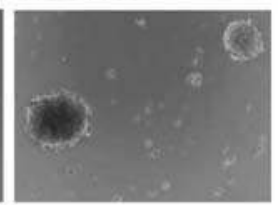

BT20

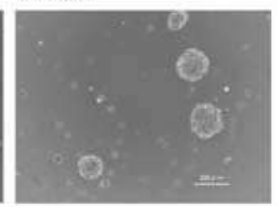

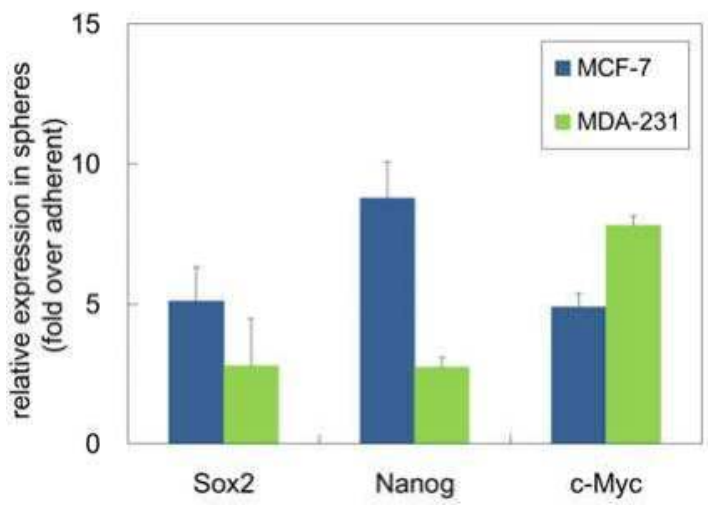

(B)

Fig. 1. Mammosphere culture in established breast cancer cell lines (A) ER-positive (MCF-7, HCC1806) and ER-negative (MDA-MB-231, BT20) breast cancer cell lines were seeded in stem cell medium in ultra-low attachment dishes (Corning). After 7 days, mammospheres were observed in MCF-7, HCC1806, and BT20 cells. MDA-MB-231 cells produced loosely adherent cell clumps. (B) Expression of stemness markers in sphere culture from MCF-7 and MDA-MB-231 cells

Subsequently, the sphere culture technique was applied to grow stem cell populations from a variety of clinical cancer samples or cancer cell lines, such as brain cancers (Galli et al., 2004; Singh et al., 2003, 2004). We also applied this approach to form non-adherent 
mammospheres using established human cancer cell lines, such as MCF-7 (Hirata et al., 2010). As shown in Fig. 1A, both estrogen receptor (ER)-positive and ER-negative breast cancer cell lines can grow as mammospheres in stem cell medium without serum that is supplemented with growth factors such as basic FGF and $\mathrm{N}_{2}$. Compared with adherent cells, sphere cells from MCF-7 and MDA-MB-231 cells exhibited higher expression of stemness markers such as Nanog, Sox2, and c-Myc, suggesting that they have self-renewal properties (Fig. 1B). In addition, sphere cells have shown high tumorigenicity when injected in immunodeficient mice (Fillmore \& Kuperwasser, 2008).

Thus, the sphere assay might represent a potentially valid and useful technique for enrichment of CSCs from clinical specimens or cell lines. However, the stem cell population cannot be purified completely by the sphere technique because CSCs from primary tumors are highly variable (Visvader \& Lindeman, 2008) and it is possible that the stem cell population is contaminated with more differentiated cells. Therefore, further purification of CSCs by flow cytometry would be required for CSC characterization.

\section{Surface markers}

Expression of cell surface markers has been widely used to isolate normal stem cells and the choice of markers varies among tissues and species. As shown in Table 1, CSCs have been isolated by various markers from many types of cancers and these cell surface markers are similar to their normal counterparts.

\begin{tabular}{|c|c|c|c|}
\hline Tumor type & Surface markers & References & Year \\
\hline Acute myeloid leukemia & $\mathrm{CD} 4^{+} / \mathrm{CD} 38^{-}$ & Bonnet \& Dick & 1997 \\
\hline Breast & $\mathrm{CD}_{44^{+}} / \mathrm{CD} 24^{-}$ & Al-Hajj et al. & 2003 \\
\hline Brain & $\mathrm{CD} 133^{+}$ & Singh et al. & 2003 \\
\hline Prostate & $\mathrm{CD} 133^{+}$ & Miki et al. & 2004 \\
\hline Colon & $\mathrm{CD} 133^{+}$ & $\mathrm{O}^{\prime}$ Brien et al. & 2005 \\
\hline Melanoma & $\mathrm{CD} 20^{+}$ & Fang et al. & 2005 \\
\hline Head and neck & $\mathrm{CD}_{4} 4^{+}$ & Prince et al. & 2007 \\
\hline Pancreas & $\mathrm{CD} 133^{+} / \mathrm{CXCR}^{+}$ & Hermann et al. & 2007 \\
\hline Ovary & $\mathrm{CD}_{4} 4^{+} / \mathrm{CD}_{24}{ }^{+} / \mathrm{ESA}^{+}$ & Zhang et al. & 2008 \\
\hline Glioblastoma & $\mathrm{CD} 49 \mathrm{f}^{+}$ & Lathia et al. & 2010 \\
\hline
\end{tabular}

Table 1. Distinct surface markers for isolation of CSCs from different cancer types

\section{$3.1 \mathrm{CD}^{+} 4^{+} / \mathrm{CD}^{-} 8^{-}$}

As described in the Introduction, CD34+/CD38- cell population has been identified as a cell surface marker on leukemic CSCs. This CD34 ${ }^{+} / \mathrm{CD} 38^{-}$cell population had the capacity to initiate leukemia in NOD-SCID mice when compared with CD34- and CD34 ${ }^{+} / \mathrm{CD} 38^{+}$cell population (Bonnet \& Dick, 1997). Although the identification of leukemic CSCs was a major advancement in stem cell field, this subpopulation is still considered heterogeneous (Sarry et al., 2011). A strict definition of leukemic CSCs is necessary to further target these cells. 


\section{$3.2 \mathrm{CD}^{+} 4^{+} / \mathrm{CD}^{-} 4^{-}$}

Al-Hajj et al. found CSCs in human solid tumors by using CD44 ${ }^{+} \mathrm{CD} 24-/$ low in breast cancer cells (Al-Hajj et al., 2003). As few as 200 cells from this subpopulation were able to form tumors when injected into NOD/SCID mice, whereas tens of thousands of other cells did not form tumors (Al- Hajj et al., 2003). The tumors from this subpopulation recapitulated the phenotypic heterogeneity of the initial tumor, containing a minority of CD44+CD24-/low cells. The CD44 ${ }^{+} \mathrm{CD} 24$-/low phenotype has been used to identify and isolate CSCs from breast cancer specimens after in vitro expansion (Ponti et al., 2005) and from breast cancer cell lines (Fillmore \& Kuperwasser, 2008). In addition to breast cancer, CSCs in ovarian cancer cells have been isolated by using CD44+/CD24- (Zhang et al., 2008).

Cancer cell lines that are enriched in $\mathrm{CD} 44^{+} \mathrm{CD} 24$-/low cells are not more tumorigenic than cell lines that contain only $5 \%$ of cells with the same phenotype (Fillmore \& Kuperwasser, 2008), suggesting that CD44+/CD24-/low cells are heterogeneous and only a subgroup within the $\mathrm{CD} 44^{+} \mathrm{CD} 24-/$ low cells is self-renewing.

\subsection{CD133}

CD133, also known as PROML1 or prominin, is a transmembrane glycoprotein that was identified in mouse neuroepithelial stem cells (Weigmann et al., 1997) and human hematopoietic stem cells (Miraglia et al., 1997). CD133 was also found on progenitor cells in endothelial cells (Peichev et al., 2000), lymphangiogenic cells (Salven et al., 2003) and myoangiogenic cells (Shmelkov et al., 2005). Although its biological function is still unclear, CD133 has been recognized as a putative CSC marker for brain, colon, and prostate cancers (Miki et al., 2007; O'Brien et al., 2007; Ricci-Vitiani et al., 2007; Richardson et al., 2004; Singh et al., 2004). In addition, CD133 ${ }^{+}$CXCR4 ${ }^{+}$CSCs were found at the invasive front of pancreatic tumors and possibly determine the metastatic phenotype of individual tumors (Hermann et al., 2007).

However, several reports have shown that CD133- cells have properties of self-renewal. For example, the CD133- population in colon cancer cells was capable of self-renewal and tumorigenicity (Shmelkov et al., 2008). CD133- cells derived from several glioma patients were tumorigenic in nude rats and several of the resulting tumors contained $\mathrm{CD}_{133^{+}}$cells (Wang et al., 2008). Taken together, these data suggest that CD133 is not an appropriate marker for isolation of CSCs in some solid tumors.

\subsection{ATP-binding cassette sub-family B member 5 (ABCB5)}

Schatton et al. identified an $\mathrm{ABCB}^{+}$subpopulation of melanoma cells that showed a high capacity for re-establishing malignancy after xenotransplantation into mice (Schatton et al., 2008). In addition, this group reported that systemic administration of monoclonal antibodies against ABCB5 induces antibody-dependent cell-mediated cytotoxicity in ABCB5+ malignant melanoma initiating cells and exerts tumor-inhibitory effects in a xenograft model. Quintana et al. showed that the frequency of CSCs in human melanoma might depend on the conditions of the xenotransplantation assay using NOD/SCID/IL2R $\gamma \mathrm{c}^{\text {null }}$ mice (Quintana et al., 2008). Further investigation is required to elucidate the phenotypic differences between tumorigenic and non-tumorigenic cell populations. 


\subsection{Integrin $\alpha 6 / C D 49 f$}

Integrin $\alpha 6$ (CD49f) is expressed in the stem cells of several tissues including epidermal, keratinocyte, and mammary stem cells (Fortunel et al., 2003; Jones \& Watt 1993; Li et al., 1998). A small subpopulation of mouse mammary stem cells, sorted as CD45-/Ter119/CD31-/Sca-1low/CD24med/CD49fhigh, was used to purify a rare subset of adult mouse mammary stem cells that were able to individually regenerate an entire mammary gland in vivo (Stingl et al., 2006).

Lathia et al. reported that CSCs in glioblastomas express high levels of integrin $\alpha 6$. In addition, targeting integrin $\alpha 6$ inhibits self-renewal, proliferation, and tumor formation, suggesting that it is a possible therapeutic target (Lathia et al., 2010). Another study showed that knockdown of $\alpha 6$-integrin causes mammosphere-derived cells to lose their ability to grow as mammospheres and abrogates their tumorigenicity in mice, suggesting that integrin $\alpha 6$ is a potential therapeutic target for breast cancer stem cells (Cariati et al., 2008).

As described above, surface markers are very useful tools to isolate and enrich CSCs from a variety of cancer cells. However, expression of these markers is not adequate for the complete purification of CSCs. Moreover, there are currently no universal surface markers for a pure population of CSCs. Since surface markers are also expressed on normal stem cells and these normal stem cells may contaminate the CSC population, more specific markers need to be determined.

\section{Side population}

In contrast to cell-type specific surface markers, the use of Hoechst 33342 dye to identify and isolate CSCs as a side population (SP) overcomes the barrier of diverse phenotype markers and replaces it with more direct functional markers (Hadnagy et al., 2006).

SP cells were identified in normal murine hematopoietic stem cells. The method is based on the efficient and specific efflux of the fluorescent DNA-binding dye Hoechst 33342 by an ATP-binding cassette $(\mathrm{ABC})$ transporter. By monitoring the blue and red fluorescence emission of Hoechst 33342 following UV excitation, a very small subpopulation of cells was observed that displayed low blue and red fluorescence (Goodell et al, 1996).

Kondo et al. were the first to report SP cells in rat C6 glioma cell line (Kondo et al., 2004). Because SP cells show resistance to anti-cancer drugs due to rapid efflux of those compounds and exhibit higher tumorigenicity than non-SP cells, the SP phenotype defines a type of CSC. Following this finding, SP cells have been identified in various established cell lines (Nakanishi et al., 2010) and tumor specimens (Hirschmann-Jax et al., 2004).

Consistent with these data, we also detected SP cells in human MCF-7 breast cancer cells (Fig. 2). To determine the gate of the $\mathrm{SP}$, it is important to use an $\mathrm{ABC}$ transporter-blocking agent such as verapamil or reserpine as a control. In the case of MCF-7 cells, reserpine was more effective than verapamil in inhibiting efflux of Hoechst 33342 by SP cells. In contrast to MCF-7 cells, SP cells have not been observed in human MDA-MB-231 breast cancer cells (data not shown). Therefore, SP cells might not be universal among cell lines. The SP technique could help to identify more specific CSC markers by comparing the expression profiles of SP and non-SP cells. 

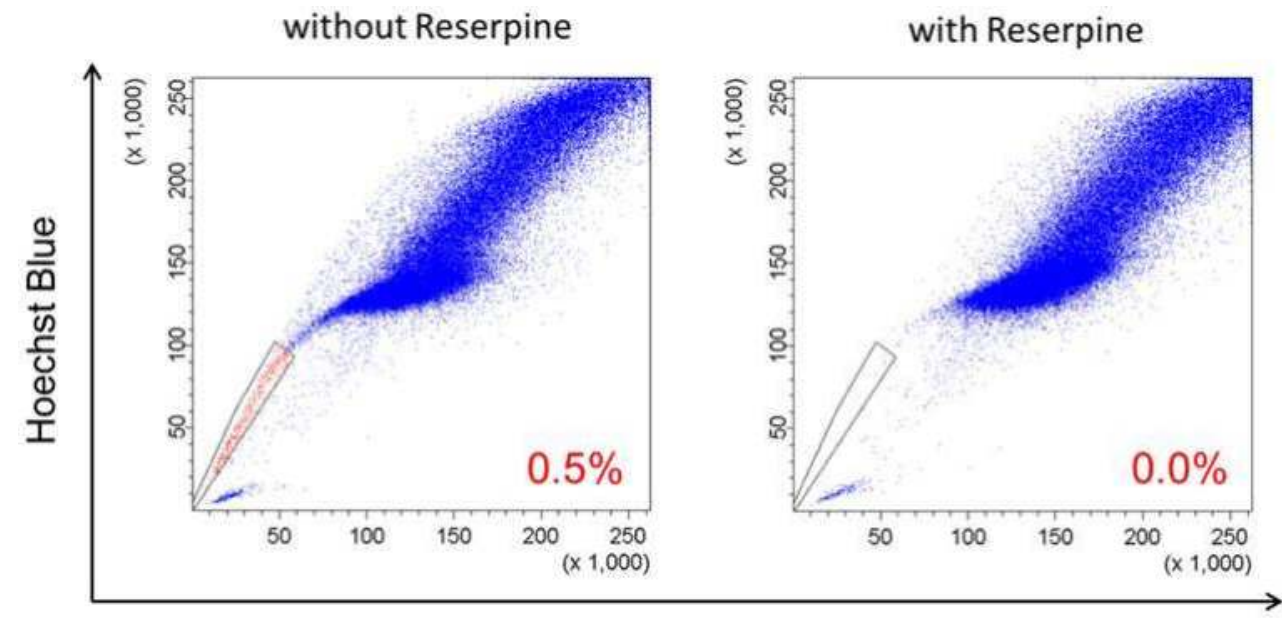

Fig. 2. Side population assay in human MCF-7 breast cancer cells MCF-7 cells were stained with Hoechst 33342 in the absence or presence of reserpine, an inhibitor of $A B C$ transporter, and analyzed by flow cytometry

SP cells are heterogeneous and vary according to tissue type, stage of development, and method of preparation (Uchida et al., 2004). Although SP cells are usually enriched in primitive stem cells, some reports suggest that SP cells do not distinguish stem cells (Triel et al., 2004).

\section{ALDEFLUOR assay}

Similar to the SP assay, the ALDEFLUOR dye has been developed as a direct functional marker of CSCs. The aldehyde dehydrogenase (ALDH) family of cytosolic isoenzymes is responsible for oxidizing intracellular aldehydes, leading to the oxidation of retinol to retinoic acid. Increased ALDH activity has been described in human hematopoietic stem cells (Hess et al., 2004). As few as 10 ALDEFLUOR-positive cells isolated from the rat hematopoietic system were capable of long-term repopulation of bone marrow upon transplantation in sub-lethally irradiated animals.

ALDEFLUOR staining uses an ALDH substrate, BODIPY-aminoacetaldehyde (BAAA). BAAA is transported into living cells through passive diffusion and is converted into the reaction product BODIPY-aminoacetate (BAA-) by intracellular ALDH. BAA- is retained inside cells and becomes brightly fluorescent (Christ et al., 2007). A specific ALDH inhibitor, diethylaminobenzaldehyde (DEAB), is used to determine background fluorescence. Thus, the cells that have high ALDH activity can be detected in the green fluorescence channel by standard flow cytometry. As shown in Fig. 3, we have shown that both MCF-7 and MDAMB-231 cells contain ALDEFLUOR-positive cells. The proportion of ALDEFLUOR-positive cell was varied by fetal bovine serum (FBS) concentration (unpublished data).

This method has been used to isolate CSCs from breast cancer cells as well as multiple myeloma and leukemia cells (Matsui et al., 2004; Pearce et al., 2005). CSCs with high ALDH activity have been shown to generate tumors in NOD/SCID mice with phenotypic 
characteristics resembling the parental tumor (Ginestier et al., 2007). In addition, ALDH expression is associated with poor prognosis in breast cancer (Ginestier et al., 2007; Marcato et al., 2011).
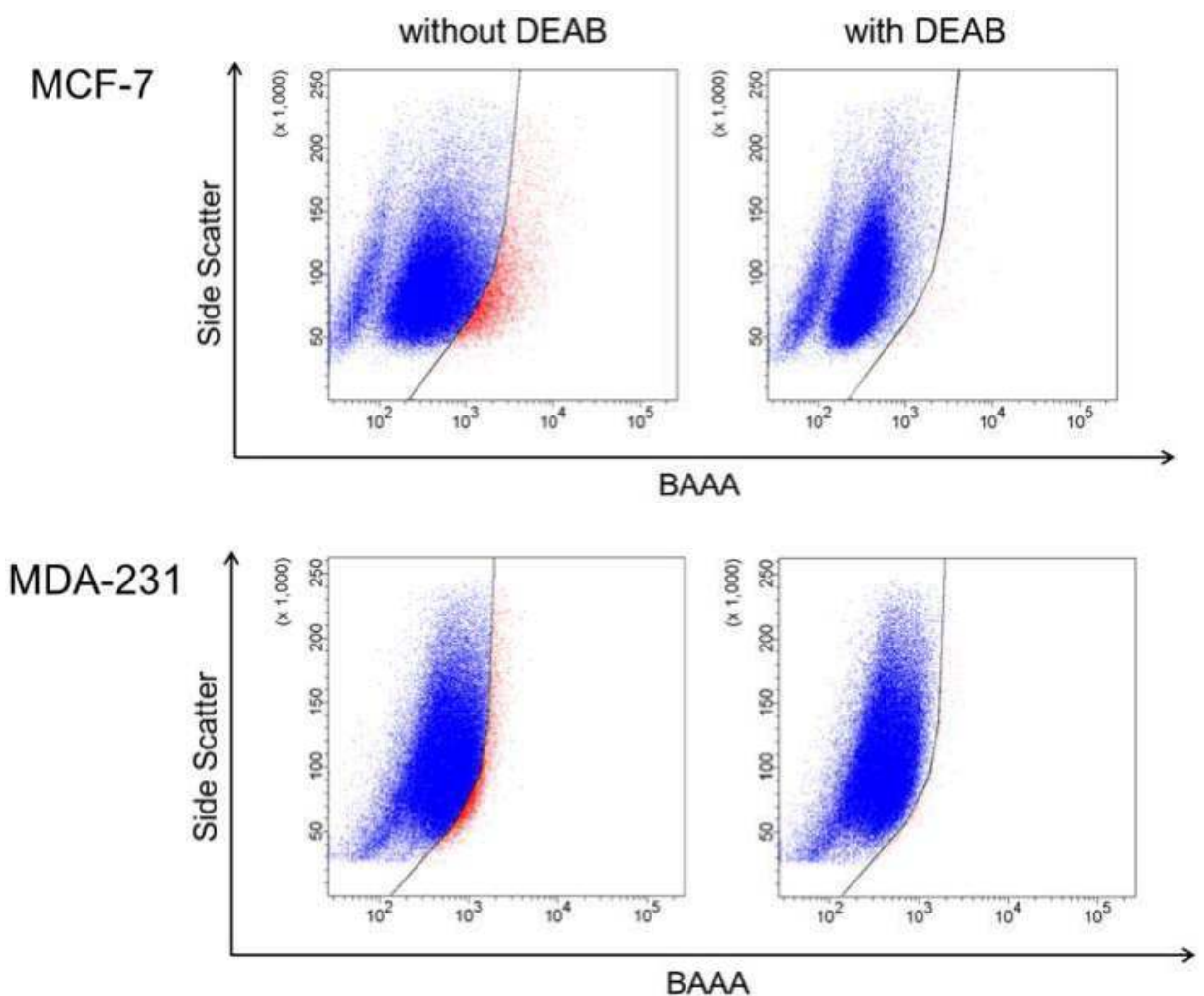

Fig. 3. ALDEFLUOR assay in human breast cancer cell lines MCF-7 and MDA-MB-231 cells were incubated with ALDEFLUOR substrate BAAA alone (left) or in the presence of the ALDH inhibitor DEAB (right), and then analyzed by flow cytometry. DEAB was used to establish the baseline fluorescence of these cells (shown in blue) and to define the ALDEFLUOR-positive region (shown in red)

Although the ALDEFLUOR assay is a potential protocol for CSC isolation, there are several limitations of this technique in certain tumors. For example, both ALDEFLUOR ${ }^{\text {br }}$ and ALDEFLUOR ${ }^{\text {low }}$ cells from the H522 lung carcinoma cell line were able to initiate tumors after transplantation into NOD/SCID mice. Moreover, tumors generated from ALDEFLUORlow cells grew faster and were larger than the tumors from ALDEFLUOR ${ }^{\text {br }}$ cells (Ucar et al., 2009). These results suggest that the ALDEFLUOR assay is not suitable for lung CSCs.

Another problem is that the stem cell population identified using the ALDEFLUOR assay is presumably heterogeneous and must be dissected using additional surface markers. In breast cancer cell lines, cell selection using the $\mathrm{CD} 44^{+} / \mathrm{CD} 24-/ \mathrm{ALDH}^{+}$phenotype increases 
the tumorigenicity of breast cancer cells in comparison with $\mathrm{CD} 44^{+} / \mathrm{CD} 24-$ or $\mathrm{ALDH}^{+}$cells (Ginestier et al., 2007). This suggests that CSCs obtained with a given marker can be further divided into distinct metastatic or non-metastatic subpopulations using additional markers. These data open new possibilities for cancer stem cell biology with therapeutic applications using marker combinations.

\section{CSCs in human cancer cell lines}

According to the CSC model, new cancer therapies should focus on targeting and eliminating CSCs, which requires the ability to characterize CSCs.

Clinical CSC samples are difficult to obtain and expand in vitro. A large number of cells should be required for high-throughput screening of lead compounds or drug development. Our experience with breast cancer cells obtained from clinical tumors indicates that a common, distinctive feature of breast CSCs is currently not available.

As described in the section 2, the capability to form non-adherent spheres has been recognized in cancer cell lines that have been established from different solid tumor types. In addition, CSCs isolated by several approaches from established cancer cell lines can be considered models of direct xenografts in immunodeficient mice. Compared with clinical CSCs, the CSCs in human cancer cell lines are easily accessible and provide a simple model for obtaining reproducible results.

For example, we have found that a concentration of nicotine closely related to the blood concentration in cigarette smokers $(10 \mathrm{nM}-10 \mu \mathrm{M})$ increases a proportion of $\mathrm{ALDH}^{+}$ population in MCF-7 cells (Hirata et al, 2010). This population, which formed mammospheres, was characterized with respect to Notch signaling. Fillmore et al. reported that the estrogen/FGF/Tbx3 signaling axis has been shown to regulate CSC numbers both in vitro and in vivo by using a proportion of the $\mathrm{CD} 44^{+} / \mathrm{CD} 24^{-} / \mathrm{ESA}^{+}$population in MCF-7 cells (Fillmore et al., 2010). Curcumin, a phytochemical compound from the Indian spice turmeric, decreased the SP population in rat C6 glioma cells (Fong et al., 2010). Given that many human cancer cell lines have been used to test the functions of oncogenes and for anticancer drug screening, CSCs in human cancer cell lines can serve as a good model for both drug discovery and elucidating the mechanism of disease.

Various drug-screening platforms that were specifically designed to target CSCs have begun to identify novel anti-cancer drugs (Pollard et al., 2009; Gupta et al., 2009). RNA interference libraries also can be screened to identify factors that control CSC tumorigenicity (Wurdak et al., 2010). However, considerable effort should be made to assess the validity, optimal experimental conditions, and the genetic stability of the screening system (van Staveren et al., 2009).

\section{Self-renewal pathways of CSCs}

The CSC model provides therapeutic strategies beyond traditional anti-proliferative agents (Zhou et al., 2009). A potential approach to eliminating CSCs is blocking the essential selfrenewal signaling pathway for CSC survival. Since self-renewal is critical for both normal stem cells and CSCs, common self-renewal pathways presumably exist among them. In addition, these self-renewal pathways might be more conserved than surface markers 
among CSCs. Taken together, these observations suggest that the search for drugs that target this common mechanism would be a powerful strategy for drug discovery.

It has been suggested that specific signaling pathways such as Notch, Wnt/ $\beta$-catenin, and Hedgehog play a role in the self-renewal and differentiation of normal stem cells. Alterations in genes that encode signaling molecules belonging to these pathways have been found in human tumor samples (Lobo et al, 2007; Sánchez-García et al., 2007), suggesting that they are likely involved in CSC regulation (Fig. 4).

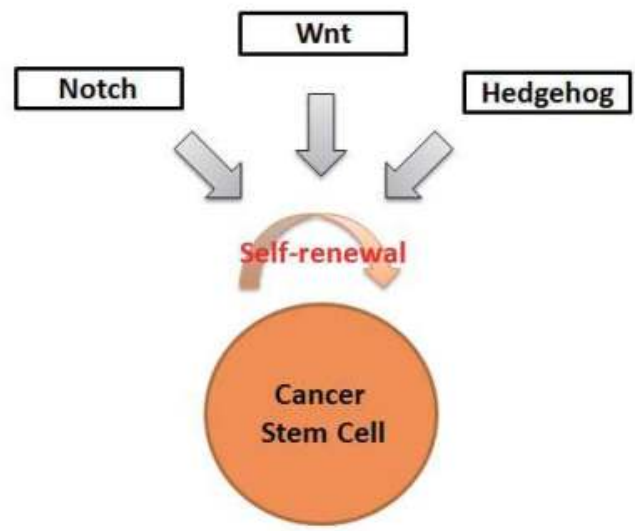

Fig. 4. Self-renewal signaling pathways in CSCs. CSCs are thought to share many molecular similarities with normal stem cells

\subsection{Notch}

The Notch signaling pathway plays an important role in the maintenance of a variety of adult stem cells, including breast (Dontu et al., 2004), neural (Hitoshi et al., 2002) and intestinal (Fre et al., 2005) stem cells, by promoting self-renewal.

Components of the Notch pathway reportedly act as oncogenes in a wide range of human tumors including breast cancers and gliomas (Kanamori et al., 2007; Reedijk et al., 2005; Stylianou et al., 2006). In addition, breast CSCs have been shown to exist within breast cell lines and primary samples and to self-renew via the Notch pathway (Harrison et al., 2010). Neurospheres derived from human glioblastoma specimens have been shown to grow via the Notch-dependent pathway (Fan et al., 2010).

$\mathrm{Y}$-Secretase inhibitors, which inhibit cleavage of activated Notch receptors and thereby prevent Notch signaling, may be a promising approach for clinical trial. MK-0752, one of $\gamma^{-}$ Secretase inhibitors, is currently undergoing clinical trials as a target for breast cancer stem cells after chemotherapy (ClinicalTrials.gov, number NCT00645333) and recurrent CNS malignancies (Fouladi et al., 2011).

\subsection{Wnt/ß-catenin}

The Wnt/ $\beta$-catenin signaling pathway plays an important role in embryonic development (Clevers, 2006). This pathway is considered a master switch that controls proliferation 
versus differentiation in both stem cell and cancer cell maintenance and growth in intestinal, epidermal, and hematopoietic tissues (Van der Wetering et al., 2002; Reya \& Clevers, 2005). Wnt pathways are commonly hyperactivated in tumors and are required for sustained tumor growth (Reya \& Clevers, 2005).

Several small molecule inhibitors of Wnt/ $\beta$-catenin signaling have been developed. ICG-001 selectively antagonizes interactions between $\beta$-catenin and the cyclic AMP response element-binding protein (CBP), which is a transcriptional co-activator essential for $\beta$ catenin-mediated transcription (Emami et al., 2004). NSC668036 binds to the PDZ domain of the Wnt-pathway signaling molecule Disheveled and mimics the endogenous Wnt inhibitor Dapper1 (Zhang et al., 2006). XAV939 selectively inhibits $\beta$-catenin-mediated transcription. This inhibitor stimulates $\beta$-catenin degradation by stabilizing axin, which is a member of the destruction complex that induces ubiquitin-mediated degradation of $\beta$-catenin (Huang et al., 2009). Among these Wnt inhibitors, an ICG-001 analog (known as PRI-721) is currently being tested in a clinical trial in patients with gastrointestinal cancers.

\subsection{Hedgehog}

The Hedgehog signaling pathway was initially identified in Drosophila as a mediator of segmental patterning during development (Nusslein-Volhard \& Wieschaus, 1980). This pathway is also essential for maintaining the normal adult stem cell population (Ingham \& McMahon, 2001).

Xu et al. identified a Hedgehog-dependent subset of brain tumor stem cells (Xu et al., 2008). Inhibition of Hedgehog signaling has been shown to be effective in a pancreatic cancer xenograft model (Jimeno et al., 2009). Moreover, the Hedgehog pathway has also been implicated in maintaining human leukemic CSCs (Dierks et al., 2008; Zhao et al., 2009). Loss of smoothened, which is a Hedgehog pathway component, resulted in depletion of chronic myeloid CSCs.

Based on these data, many inhibitors of this pathway are currently under development (Mahindroo et al., 2009). For example, GDC-0449 was originally identified as a smoothened antagonist in a chemical compound screen (Robarge et al., 2009) and has been used in a clinical trial in solid tumor patients (Von Hoff et al., 2009). BMS-833923 (XL139) was also used in a clinical trial for uncontrolled basal cell nevus syndrome (Siu et al., 2010).

\section{Conclusions}

CSCs play a central role in the field of cancer biology and evidence is accumulating that CSCs are involved in tumorigenesis and response to therapy. Although the contribution of CSCs to cancer development is still unclear, targeting CSCs is a potential approach for discovering new drugs that eliminate all cancer cells and finding effective and clinically applicable therapies that prevent disease recurrence and metastasis.

CSC populations in established cancer cell lines are considered good in vitro models. These CSCs can be easily isolated with the protocols described herein and are useful for chemical screening. However, CSC isolation protocols and the efficiency of purification should be improved. The percentage of CSCs in cell lines, their capability to form tumors, and their self-renewal potential can widely vary. In addition, it is essential to investigate whether the 
CSCs identified in cancer cell lines have the same properties as the CSCs obtained from patient specimens. Future studies are required to evaluate CSC phenotypes.

Development of new therapies for targeting CSCs must consider both the differences between CSCs and other tumor cells and the signaling pathways shared between CSCs and normal stem cells. Elucidation of the specific mechanisms by which CSCs regulate selfrenewal will be useful for the design of new therapeutic alternatives. CSC-targeted therapies should avoid or minimize the potential toxic side effects to normal tissue stem cells.

\section{Acknowledgments}

This work was supported by a grant from Health Sciences of the National Institute of Biomedical Innovation (No. 09-02), a Grant-in-Aid for Scientific Research from the Ministry of Education, Culture, Sports, Science, and Technology, Japan (No. 23590322) and a Health and Labour Sciences Research Grant from the Ministry of Health, Labour and Welfare, Japan, and a grant from the Smoking Research Foundation.

\section{References}

Al-Hajj M., Wicha M.S., Benito-Hernandez A., Morrison S.J. \& Clarke M.F. (2003). Prospective identification of tumorigenic breast cancer cells. Proc Natl Acad Sci USA 100, 3983-8.

Bonnet D. \& Dick J.E. (1997). Human acute myeloid leukemia is organized as a hierarchy that originates from a primitive hematopoietic cell. Nat Med 3, 730-7.

Cariati M., Naderi A., Brown J.P., Smalley M.J., Pinder S.E., Caldas C. \& Purushotham A.D. (2008). $\alpha-6$ integrin is necessary for the tumourigenicity of a stem cell-like subpopulation within the MCF7 breast cancer cell line. Int J Cancer 122, 298-304.

Christ O., Lucke K., Imren S., Leung K., Hamilton M., Eaves A., Smith C. \& Eaves C. (2007). Improved purification of hematopoietic stem cells based on their elevated aldehyde dehydrogenase activity, Haematologica 92, 1165-72.

Clevers H. (2006). Wnt/ $\beta$-catenin signaling in development and disease. Cell 127, 469-80.

Collins A.T., Berry P.A., Hyde C., Stower M.J. \& Maitland N.J. (2005). Prospective identification of tumorigenic prostate cancer stem cells. Cancer Res 65, 10946-51.

Curley M.D., Therrien V.A., Cummings C.L., Sergent P.A., Koulouris C.R., Friel A.M., Roberts D.J., Seiden M.V., Scadden D.T., Rueda B.R. \& Foster R. (2009). Cd133 expression defines a tumor initiating cell population in primary human ovarian cancer. Stem Cells 27, 2875-83.

Dalerba P., Dylla S.J., Park I.K., Liu R., Wang X., Cho R.W., Hoey T., Gurney A., Huang E.H., Simeone D.M., Ricci-Vitiani L., Lombardi D.G., Pilozzi E., Biffoni M., Todaro M., Peschle C. \& De Maria R. (2007). Identification and expansion of human coloncancer-initiating cells. Nature 445, 111-5.

Dierks C., Beigi R., Guo G.R., Zirlik K., Stegert M.R., Manley P., Trussell C., Schmitt-Graeff A., Landwerlin K., Veelken H. \& Warmuth M. (2008). Expansion of Bcr-Ablpositive leukemic stem cells is dependent on Hedgehog pathway activation. Cancer Cell 14, 238-49. 
Dontu G., Abdallah W.M., Foley J.M., Jackson K.W., Clarke M.F., Kawamura M.J. \& Wicha M.S. (2003). In vitro propagation and transcriptional profiling of human mammary stem/progenitor cells. Genes Dev 17, 1253-70.

Dontu G., Jackson K.W., McNicholas E., Kawamura M.J., Abdallah W.M. \& Wicha MS. (2004). Role of Notch signaling in cell-fate determination of human mammary stem/progenitor cells. Breast Cancer Res 6, R605-15.

Emami K.H., Nguyen C., Ma H., Kim D.H., Jeong K.W., Eguchi M., Moon R.T., Teo J.L., Kim H.Y., Moon S.H., Ha J.R. \& Kahn M. (2004). A small molecule inhibitor of $\beta$ catenin/CREB-binding protein transcription. Proc Natl Aca Sci USA 101, 12682-7.

Fan X., Khaki L., Zhu T.S., Soules M.E., Talsma C.E., Gul N., Koh C., Zhang J., Li Y.M., Maciaczyk J., Nikkhah G., Dimeco F., Piccirillo S., Vescovi A.L., Eberhart C.G. (2010). NOTCH pathway blockade depletes CD133-positive glioblastoma cells and inhibits growth of tumor neurospheres and xenografts. Stem Cells 28, 5-16.

Fang D, Nguyen TK, Leishear K, Finko R, Kulp AN, Hotz S, Van Belle PA, Xu X, Elder DE, Herlyn M. (2005). A tumorigenic subpopulation with stem cell properties in melanomas. Cancer Res 65, 9328-37.

Fillmore CM, Gupta PB, Rudnick JA, Caballero S, Keller PJ, Lander ES, and Kuperwasser C. Estrogen expands breast cancer stem-like cells through paracrine FGF/Tbx3 signaling. Proc Natl Acad. Sci USA 107, 21737-42.

Fillmore C.M. \& Kuperwasser C. (2008). Human breast cancer cell lines contain stem-like cells that self-renew, give rise to phenotypically diverse progeny and survive chemotherapy. Breast Cancer Res 10(2), R25.

Fong D., Yeh A., Naftalovich .R, Choi T.H. \& Chan M.M. (2010). Curcumin inhibits the side population (SP) phenotype of the rat C6 glioma cell line: towards targeting of cancer stem cells with phytochemicals. Cancer Lett 293, 65-72.

Fortunel N.O., Otu H.H., Ng H.H., Chen J., Mu X., Chevassut T., Li X., Joseph M., Bailey C., Hatzfeld J.A., Hatzfeld A., Usta F., Vega V.B., Long P.M., Libermann T.A., Lim B. (2003). Comment on " 'Stemness': transcriptional profiling of embryonic and adult stem cells" and "a stem cell molecular signature". Science 302, 393.

Fre S., Huyghe M., Mourikis P., Robine S., Louvard D \& Artavanis-Tsakonas S. (2005). Notch signals control the fate of immature progenitor cells in the intestine. Nature 435, 964-8.

Fouladi M., Stewart C.F., Olson J., Wagner L.M., Onar-Thomas A., Kocak M., Packer R.J., Goldman S., Gururangan S., Gajjar A., Demuth T., Kun L.E., Boyett J.M. \& Gilbertson RJ. (2011). Phase I trial of MK-0752 in children with refractory CNS malignancies: a pediatric brain tumor consortium study. J Clin Oncol 29, 3529-34.

Galli R., Binda E., Orfanelli U., Cipelletti B., Gritti A., De Vitis S., Fiocco R., Foroni C., Dimeco F. \& Vescovi A. (2004). Isolation and characterization of tumorigenic, stemlike neural precursors from human glioblastoma. Cancer Res 64, 7011-21.

Ginestier C., Hur M.H., Charafe-Jauffret E., Monville F., Dutcher J., Brown M., Jacquemier J., Viens P., Kleer C.G., Liu S., Schott A., Hayes D., Birnbaum D., Wicha M.S. \& Dontu G. (2007). ALDH1 is a marker of normal and malignant human mammary stem cells and a predictor of poor clinical outcome. Cell Stem Cell 1, 555-67. 
Goodell M.A., Brose K., Paradis G., Conner A.S. \& Mulligan R.C. (1996). Isolation and functional properties of murine hematopoietic stem cells that are replicating in vivo. J Exp Med 183, 1797-806

Gupta P.B., Onder T.T., Jiang G., Tao K., Kuperwasser C., Weinberg R.A., Lander E.S. (2009). Identification of selective inhibitors of cancer stem cells by high-throughput screening. Cell 138, 645-59.

Gupta P.B., Fillmore C.M., Jiang G., Shapira S.D., Tao K., Kuperwasser C., Lander E.S. (2011). Stochastic state transitions give rise to phenotypic equilibrium in populations of cancer cells. Cell 146, 633-44.

Hadnagy A., Gaboury L., Beaulieu R. \& Balicki D. (2006). SP analysis may be used to identify cancer stem cell populations. Exp Cell Res 312, 3701-10.

Harrison H., Farnie G., Howell S.J., Rock R.E., Stylianou S., Brennan K.R., Bundred N.J. \& Clarke R.B. (2010). Regulation of breast cancer stem cell activity by signaling through the Notch4 receptor. Cancer Res 70, 709-18.

Hermann P.C., Huber S.L., Herrler T., Aicher A., Ellwart J.W., Guba M., Bruns C.J. \& Heeschen C. (2007). Distinct populations of cancer stem cells determine tumor growth and metastatic activity in human pancreatic cancer. Cell Stem Cell 1, 313-23.

Hess D.A., Meyerrose T.E., Wirthlin L., Craft T.P., Herrbrich P.E., Creer M.H. \& Nolta J.A. (2004). Functional characterization of highly purified human hematopoietic repopulating cells isolated according to aldehyde dehydrogenase activity. Blood 104, 1648-55.

Hiramoto T., Kanda Y., Satoh Y., Takishima K. \& Watanabe Y. (2007). Dopamine D2 receptor stimulation promotes the proliferation of neural progenitor cells in adult mouse hippocampus. Neuroreport 18, 659-64.

Hirata N., Sekino Y. \& Kanda Y. (2010). Nicotine increases cancer stem cell population in MCF-7 cells, Biochem Biophys Res Commun 403, 138-43.

Hirschmann-Jax C., Foster A.E., Wulf G.G., Nuchtern J.G., Jax T.W., Gobel U., Goodell M.A. \& Brenner M.K. (2004). A distinct "side population" of cells with high drug efflux capacity in human tumor cells. Proc Natl Acad Sci USA 101, 14228-33.

Hitoshi S., Alexson T., Tropepe V., Donoviel D., Elia A.J., Nye J.S., Conlon R.A., Mak T.W., Bernstein A. \& van der Kooy D. (2002). Notch pathway molecules are essential for the maintenance, but not the generation, of mammalian neural stem cells. Genes Dev 16, 846-58.

Holmberg J., Armulik A., Senti K.A., Edoff K., Spalding K., Momma S., Cassidy R., Flanagan J.G.\& Frisén J. (2005). Ephrin-A2 reverse signaling negatively regulates neural progenitor proliferation and neurogenesis. Genes Dev 19, 462-71.

Huang S.M., Mishina Y.M., Liu S., Cheung A., Stegmeier F., Michaud G.A., Charlat O., Wiellette E., Zhang Y., Wiessner S., Hild M., Shi X., Wilson C.J., Mickanin C., Myer V., Fazal A., Tomlinson R., Serluca F., Shao W., Cheng H., Shultz M., Rau C., Schirle M., Schlegl J., Ghidelli S., Fawell S., Lu C., Curtis D., Kirschner M.W., Lengauer C., Finan P.M., Tallarico .JA., Bouwmeester T., Porter J.A., Bauer A. \& Cong F. (2009). Tankyrase inhibition stabilizes axin and antagonizes Wnt signalling. Nature 461, 614-20.

Ingham P.W. \& McMahon A.P. (2001). Hedgehog signaling in animal development: paradigms and principles. Genes Dev 15, 3059-87. 
Jimeno A., Feldmann G., Suárez-Gauthier A., Rasheed Z., Solomon A., Zou G.M. RubioViqueira B., García-García E., López-Ríos F., Matsui W. Maitra A. \& Hidalgo M. (2009). A direct pancreatic cancer xenograft model as a platform for cancer stem cell therapeutic development. Mol Cancer Ther 8, 310-4.

Jones PH \& Watt FM. (1993). Separation of human epidermal stem cells from transit amplifying cells on the basis of differences in integrin function and expression. Cell $73,713-24$.

Kanamori M., Kawaguchi T., Nigro J.M., Feuerstein B.G., Berger M.S., Miele L. \& Pieper R.O. (2007). Contribution of Notch signaling activation to human glioblastoma multiforme. J Neurosurg 106, 417-27.

Kondo T., Setoguchi T. \& Taga T. (2004). Persistence of a small subpopulation of cancer stem-like cells in the C6 glioma cell line. Proc Natl Acad Sci USA 101, 781-6.

Lathia J.D., Gallagher J., Heddleston J.M., Wang J., Eyler C.E., Macswords J. Wu Q., Vasanji A., McLendon R.E., Hjelmeland A.B. \& Rich J.N. (2010). Integrin $\alpha 6$ Regulates Glioblastoma Stem Cells. Cell Stem Cell 6, 421-32.

Li A., Simmons P.J. \& Kaur P. (1998). Identification and isolation of candidate human keratinocyte stem cells based on cell surface phenotype. Proc Natl Acad. Sci USA 95, 3902-7.

Lobo N.A., Shimono Y., Qian D. \& Clarke M.F. (2007). The biology of cancer stem cells. Annu Rev Cell Dev Biol 23, 675-99.

Mahindroo N., Punchihewa C. \& Fujii N. (2009). Hedgehog-Gli signaling pathway inhibitors as anticancer agents. J Med Chem 52, 3829-45.

Marcato P., Dean C.A., Pan D., Araslanova R., Gillis M., Joshi M., Helyer L., Pan L., Leidal A., Gujar S., Giacomantonio C.A. \& Lee P.W. (2011). Aldehyde dehydrogenase activity of breast cancer stem cells is primarily due to isoform ALDH1A3 and its expression is predictive of metastasis. Stem Cells 29, 32-45.

Matsui W., Huff C.A., Wang Q., Malehorn M.T., Barber J., Tanhehco Y., Smith B.D., Civin C.I. \& Jones R.J. (2004). Characterization of clonogenic multiple myeloma cells. Blood 103, 2332-6.

Miki J., Furusato B., Li H., Gu Y., Takahashi H., Egawa S., Sesterhenn I.A., McLeod D.G., Srivastava S. \& Rhim J.S. (2007). Identification of putative stem cell markers, CD133 and CXCR4, in hTERT-immortalized primary nonmalignant and malignant tumorderived human prostate epithelial cell lines and in prostate cancer specimens. Cancer Res 67, 3153-61.

Miraglia S., Godfrey W., Yin A.H., Atkins K., Warnke R., Holden J.T., Bray R.A., Waller E.K. \& Buck D.W. (1997). A novel five-transmembrane hematopoietic stem cell antigen: isolation, characterization, and molecular cloning. Blood 90, 5013-21.

Nagato M., Heike T., Kato T., Yamanaka Y., Yoshimoto M., Shimazaki T., Okano H. \& Nakahata T. (2005). Prospective characterization of neural stem cells by flow cytometry analysis using a combination of surface markers. J Neurosci Res 80, 45666.

Nakanishi T., Chumsri S., Khakpour N., Brodie A.H., Leyland-Jones B., Hamburger A.W., Ross D.D. \& Burger A.M. (2010). Side-population cells in luminal-type breast cancer have tumour-initiating cell properties, and are regulated by HER2 expression and signalling. Br J Cancer 102, 815-26. 
Nusslein-Volhard C. \& Wieschaus E. Mutations affecting segment number and polarity in Drosophila. (1980). Nature 287, 795-801.

O'Brien C.A., Pollett A., Gallinger S. \& Dick JE. (2007). A human colon cancer cell capable of initiating tumour growth in immunodeficient mice. Nature 445, 106-10.

Peukert S. \& Miller-Moslin K. (2010). Small-molecule inhibitors of the hedgehog signaling pathway ascancer therapeutics. Chem Med Chem 5, 500-12.

Pearce D.J., Taussig D., Simpson C., Allen K., Rohatiner A.Z., Lister T.A. \& Bonnet D. (2005). Characterization of cells with a high aldehyde dehydrogenase activity from cord blood and acute myeloid leukemia samples. Stem Cells 23, 752-60.

Peichev M., Naiyer A.J., Pereira D., Zhu Z., Lane W.J., Williams M., Oz M.C., Hicklin D.J., Witte L., Moore M.A. \& Rafii S. (2000). Expression of VEGFR-2 and AC133 by circulating human $\mathrm{CD} 34(+)$ cells identifies a population of functional endothelial precursors. Blood 95, 952-8.

Pollard S.M., Yoshikawa K., Clarke I.D., Danovi D., Stricker S., Russell R., Bayani J., Head R., Lee M., Bernstein M., Squire J.A., Smith A. \& Dirks P.(2009). Glioma stem cell lines expanded in adherent culture have tumor-specific phenotypes and are suitable for chemical and genetic screens. Cell Stem Cell 4, 568-80.

Ponti D., Costa A., Zaffaroni N., Pratesi G., Petrangolini G., Coradini D., Pilotti S., Pierotti M.A. \& Daidone M.G. (2005). Isolation and in vitro propagation of tumorigenic breast cancer cells with stem/progenitor cell properties. Cancer Res 65, 5506-11.

Prince M.E., Sivanandan R., Kaczorowski A., Wolf G.T., Kaplan M., Dalerba P., Weissman I.L., Clarke M.F. \& Ailles L.E. (2007). Identification of a subpopulation of cells with cancer stem cell properties in head and neck squamous cell carcinoma. Proc Natl Acad Sci USA 104, 973-8.

Quintana E., Shackleton M., Sabel M.S., Fullen D.R., Johnson T.M. \& Morrison S.J. (2008). Efficient tumor formation by single human melanoma cells. Nature 456, 593-8.

Reedijk M., Odorcic S., Chang L., Zhang H., Miller N., McCready D.R., Lockwood G. \& Egan S.E. (2005). High-level coexpression of JAG1 and NOTCH1 is observed in human breast cancer and is associated with poor overall survival. Cancer Res 65, 8530-7.

Reya T. \& Clevers H. (2005). Wnt signalling in stem cells and cancer. Nature 434, 843-50.

Reynolds B.A. \& Weiss S. (1992). Generation of neurons and astrocytes from isolated cells of the adult mammalian central nervous system. Science 255, 1707-10.

Ricci-Vitiani L., Lombardi D.G., Pilozzi E., Biffoni M., Todaro M., Peschle C. \& De Maria R. (2007). Identification and expansion of human colon-cancer-initiating cells. Nature $445,111-5$.

Richardson G.D., Robson C.N., Lang S.H., Neal D.E., Maitland N.J. \& Collins AT. (2004). CD133, a novel marker for human prostatic epithelial stem cells. J Cell Sci 117, 353945.

Robarge K.D., Brunton S.A., Castanedo G.M., Cui Y., Dina M.S., Goldsmith R., Gould S.E., Guichert O., Gunzner J.L., Halladay J., Jia W., Khojasteh C., Koehler M.F., Kotkow K., La H., Lalonde R.L., Lau K., Lee L., Marshall D., Marsters J.C. Jr, Murray L.J., Qian C., Rubin L.L., Salphati L., Stanley M.S., Stibbard J.H., Sutherlin D.P., Ubhayaker S., Wang S., Wong S. \& Xie M. (2009). GDC-0449-a potent inhibitor of the Hedgehog pathway. Bioorg Med Chem Lett 19, 5576-81. 
Salven P., Mustjoki S., Alitalo R., Alitalo K. \& Rafii S. (2003). VEGFR-3 and CD133 identify a population of CD34+ lymphatic/vascular endothelial precursor cells. Blood 101, 168-72.

Sánchez-García I., Vicente-Dueñas C. \& Cobaleda C. (2007). The theoretical basis of cancerstem-cell based therapeutics of cancer: can it be put into practice? Bioessays 29, 126980.

Sarry J.E., Murphy K., Perry R., Sanchez P.V., Secreto A., Keefer C., Swider C.R., Strzelecki A.C., Cavelier C., Récher C., Mansat-De Mas V., Delabesse E., Danet-Desnoyers G., Carroll M. (2011). Human acute myelogenous leukemia stem cells are rare and heterogeneous when assayed in NOD/SCID/IL2Ryc-deficient mice. J Clin Invest 121, 384-95.

Schatton T., Murphy G.F., Frank N.Y., Yamaura K., Waaga-Gasser A.M., Gasser M., Zhan Q., Jordan S., Duncan L.M., Weishaupt C., Fuhlbrigge R.C., Kupper T.S., Sayegh M.H. \& Frank, M.H. (2008). Identification of cells initiating human melanomas. Nature 451, 345-9.Stylianou S., Clarke R.B., Brennan K. (2006). Aberrant activation of notch signalling in human breast cancer. Cancer Res 66, 1517-25.

Shmelkov S.V., Meeus S., Moussazadeh N., Kermani P., Rashbaum W.K., Rabbany S.Y., Hanson M.A., Lane W.J., St Clair R., Walsh K.A., Dias S., Jacobson J.T., Hempstead B.L., Edelberg J.M. \& Rafii S. (2005). Cytokine preconditioning promotes codifferentiation of human fetal liver $\mathrm{CD} 133^{+}$stem cells into angiomyogenic tissue. Circulation 111, 1175-83.

Shmelkov S.V., Butler J.M., Hooper A.T., Hormigo A., Kushner J., Milde T., St Clair R., Baljevic M., White I., Jin D.K., Chadburn A., Murphy A.J., Valenzuela D.M., Gale N.W., Thurston G., Yancopoulos G.D., D'Angelica M., Kemeny N., Lyden D. \& Rafii S. (2008). CD133 expression is not restricted to stem cells, and both $\mathrm{CD}_{133^{+}}$and CD133- metastatic colon cancer cells initiate tumors. J Clin Invest 118, 2111-20.

Singh S.K., Clarke I.D., Terasaki M., Bonn V.E., Hawkins C., Squire J. \& Dirks P.B. (2003). Identification of a cancer stem cell in human brain tumors. Cancer Res 63, 5821-8.

Singh S.K., Hawkins C., Clarke I.D., Squire J.A., Bayani J., Hide T., Henkelman R.M., Cusimano M.D. \& Dirks P.B. (2004). Identification of human brain tumour initiating cells. Nature 432, 396-401.

Siu L.L., Papadopoulos K., Alberts S.R., Kirchoff-Ross R., Vakkalagadda B., Lang L., Ahlers C.M., Bennett K.L. \& Van Tornout J.M. (2010). A first-in-human, phase I study of an oral hedgehog (HH) pathway antagonist, BMS-833923 (XL139), in subjects with advanced or metastatic solid tumors. J Clin Oncol (ASCO) abstract no. 2501.

Stingl J., Eirew P., Ricketson I., Shackleton M., Vaillant F., Choi D., Li H.I. \& Eaves C.J. (2006). Purification and unique properties of mammary epithelial stem cells. Nature 439, 993-7.

Stylianou S., Clarke R.B., \& Brennan K. (2006). Aberrant activation of Notch signalling occurs in human breast cancer. Cancer Res 66, 1517-25.

Triel C., Vestergaard M.E., Bolund L., Jensen T.G., Jensen U.B. (2004). Side population cells in human and mouse epidermis lack stem cell characteristics. Exp Cell Res 295, 7990. 
Ucar D., Cogle C.R., Zucali J.R., Ostmark B., Scott E.W., Zori R., Gray B.A. \& Moreb J.S. (2009). Aldehyde dehydrogenase activity as a functional marker for lung cancer. Chem Biol Interact 178, 48-55.

Uchida N., Dykstra B., Lyons K., Leung F., Kristiansen M., Eaves C. (2004). ABC transporter activities of murine hematopoietic stem cells vary according to their developmental and activation status. Blood 103, 4487-95.

van de Wetering M., Sancho E., Verweij C., de Lau W., Oving I., Hurlstone A., van der Horn K., Batlle E., Coudreuse D., Haramis A.P., Tjon-Pon-Fong M., Moerer P., van den Born M., Soete G., Pals S., Eilers M., Medema R. \& Clevers H. (2002). The betacatenin/TCF-4 complex imposes a crypt progenitor phenotype on colorectal cancer cells. Cell 111, 241-50.

van Staveren W.C., Solís D.Y., Hébrant A., Detours V., Dumont J.E. \& Maenhaut C. (2009). Human cancer cell lines: Experimental models for cancer cells in situ? For cancer stem cells? Biochim Biophys Acta 1795, 92-103.

Visvader J.E. \& Lindeman G.J. (2008). Cancer stem cells in solid tumours: accumulating evidence and unresolved questions. Nat Rev Cancer 8, 755-68.

Von Hoff D.D., LoRusso P.M., Rudin C.M., Reddy J.C., Yauch R.L., Tibes R., Weiss G.J., Borad M.J., Hann C.L., Brahmer J.R., Mackey H.M., Lum B.L., Darbonne W.C., Marsters J.C. Jr, de Sauvage F.J. \& Low J.A. (2009). Inhibition of the Hedgehog pathway in advanced basal-cell carcinoma. N Engl J Med 361, 1164-72.

Wang J., Sakariassen P.Ø., Tsinkalovsky O., Immervoll H., Boe S.O., Svendsen A., Prestegarden L., Rosland G., Thorsen F., Stuhr L., Molven A., Bjerkvig R. \& Enger P.Ø. (2008). CD133 negative glioma cells form tumors in nude rats and give rise to CD133 positive cells. Int J Cancer 122, 761-8.

Weigmann A., Corbeil D., Hellwig A. \& Huttner W.B. (1997). Prominin, a novel microvillispecific polytopic membrane protein of the apical surface of epithelial cells, is targeted to plasmalemmal protrusions of non-epithelial cells. Proc Natl Acad Sci USA 94, 12425-30.

Weiss S., Dunne C., Hewson J., Wohl C., Wheatley M., Peterson A.C. \& Reynolds B.A. (1996). Multipotent CNS stem cells are present in the adult mammalian spinal cord and ventricular neuroaxis. J Neurosci 16, 7599-609.

Wurdak H., Zhu S., Romero A., Lorger M., Watson .J, Chiang C.Y., Zhang J., Natu V.S., Lairson L.L., Walker J.R., Trussell C.M., Harsh G.R., Vogel H., Felding-Habermann B., Orth A.P., Miraglia L.J., Rines D.R., Skirboll S.L., Schultz P.G. (2010). An RNAi screen identifies TRRAP as a regulator of brain tumor-initiating cell differentiation. Cell Stem Cell 6,37-47.

Xu Q, Yuan X, Liu G, Black KL, Yu JS. (2008). Hedgehog signaling regulates brain tumorinitiating cell proliferation and portends shorter survival for patients with PTENcoexpressing glioblastomas. Stem Cells 26, 3018-26.

Zhang L., Gao X., Wen J., Ning Y. \& Chen Y.G. (2006). Dapper 1 antagonizes Wnt signaling by promoting dishevelled degradation. J Biol Chem 281, 8607-12.

Zhang S., Balch C., Chan M.W., Lai H.C., Matei D., Schilder J.M., Yan P.S., Huang T.H., Nephew K.P. (2008). Identification and characterization of ovarian cancer-initiating cells from primary human tumors. Cancer Res 68, 4311-20. 
Zhao C., Chen A., Jamieson C.H., Fereshteh M., Abrahamsson A., Blum J., Kwon H.Y., Kim J., Chute J.P., Rizzieri D., Munchhof M., Vanarsdale T., Beachy P.A. \& Reya T. (2009). Hedgehog signalling is essential for maintenance of cancer stem cells in myeloid leukaemia. Nature 458, 776-9.

Zhou B.B., Zhang H., Damelin M., Geles K.G., Grindley J.C. \& Dirks P.B. (2009). Tumourinitiating cells: challenges and opportunities for anticancer drug discovery. Nat Rev Drug Discov 8, 806-23. 


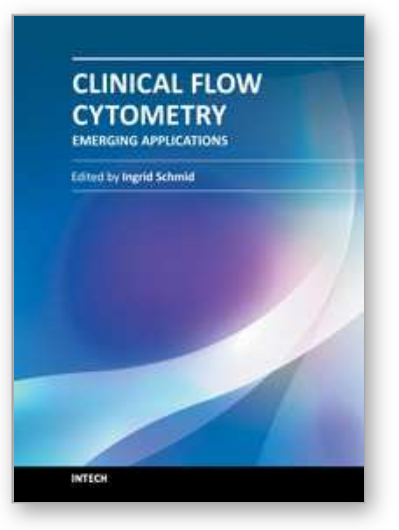

\author{
Clinical Flow Cytometry - Emerging Applications \\ Edited by M.Sc. Ingrid Schmid
}

ISBN 978-953-51-0575-6

Hard cover, 204 pages

Publisher InTech

Published online 16, May, 2012

Published in print edition May, 2012

"Clinical Flow Cytometry - Emerging Applications" contains a collection of reviews and original papers that illustrate the relevance of flow cytometry for the study of specific diseases and clinical evaluations. The chapters have been contributed by authors from a wide variety of countries showing the broad application and importance of this technology in medicine. Examples include chapters on autoimmune disease, cancer, and the evaluation of new drugs. The book is intended to give newcomers a helpful introduction, but also to provide experienced flow cytometrists with novel insights and a better understanding of clinical cytometry.

\title{
How to reference
}

In order to correctly reference this scholarly work, feel free to copy and paste the following:

Yasunari Kanda (2012). Identification and Characterization of Cancer Stem Cells Using Flow Cytometry, Clinical Flow Cytometry - Emerging Applications, M.Sc. Ingrid Schmid (Ed.), ISBN: 978-953-51-0575-6, InTech, Available from: http://www.intechopen.com/books/clinical-flow-cytometry-emerging-applications/identificationand-characterization-of-cancer-stem-cells-using-flowcytometry

\section{INTECH}

open science | open minds

\section{InTech Europe}

University Campus STeP Ri

Slavka Krautzeka 83/A

51000 Rijeka, Croatia

Phone: +385 (51) 770447

Fax: +385 (51) 686166

www.intechopen.com

\section{InTech China}

Unit 405, Office Block, Hotel Equatorial Shanghai

No.65, Yan An Road (West), Shanghai, 200040, China

中国上海市延安西路 65 号上海国际贵都大饭店办公楼 405 单元

Phone: +86-21-62489820

Fax: +86-21-62489821 
(C) 2012 The Author(s). Licensee IntechOpen. This is an open access article distributed under the terms of the Creative Commons Attribution 3.0 License, which permits unrestricted use, distribution, and reproduction in any medium, provided the original work is properly cited. 